\title{
J(৫)
}

Received: 12.10 .2019

\section{BLAŽEK, V. Altaic Languages - History of research, survey, classification, and a sketch of comparative grammar, in collaboration with M. SCHWARZ and O. SRBA, Brno: Masaryk University Press, 2019, pp. 360, ISBN: 978-80-210-9321-8}

\author{
Peter PIISPANEN \\ Stockholm University (Stockholm/Sweden) \\ E-mail: peter.piispanen@finska.su.se
}

This book review is about V. BLAžEK's book (in collaboration with M. SCHWARZ and O. SRBA) "Altaic Languages", subtitled "History of research, survey, classification, and a sketch of comparative grammar", printed at the Masaryk University Press, in Brno of the Czech Republic in 2019. The review handles both the digital and printed versions of this book. "Altaic Languages" is a timely publication about an old research field where old ideas are being evaluated and new ideas are being created.

As stated in the Preface (pages 9-14), this monograph is also called a Manual, which seems like a suitable descriptive term for it, as would be (Bibliographic) Encyclopaedia. The materials are based on no less than five different series of 


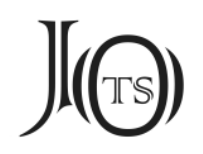

papers, some of which are printed here for the first time in English. These series are: review articles of Altaic etymologies, articles on distribution and classification of the Macro-Altaic languages and their phonology, articles on the pronominal systems of the Altaic languages, articles on Macro-Altaic numerals, and articles on the history of research and development of Altaic linguistics. While the volume is thus anthological in nature is encompasses an unusually broad concept, namely all of the Macro-Altaic languages of Turkic, Mongolic, Tungusic, Korean and Japanese. It should be noted that the book as such does not seem to be intended to defend or propose any pro- or anti-Altaistic thesis, but merely to provide an impartial overview of all research materials (history, classification, phonology, grammar, lexicon) of these languages and their interconnectedness through a comparative linguistic perspective. Even then, some pro-Altaistic food for thoughts is to be found throughout the volume (example, p. 188). A nice, and vivid touch is the continuous inclusion of quotes from various researchers in their original languages, putting things in the right perspective. It thus serves as a bibliographic source with referential functions, where, in the synthesis, many new ideas in all fields of research are also included and presented not found elsewhere.

In the Preface, it also becomes clear that this monograph was written by a group of three linguists with particular strengths complementing each other well in this type of endeavour. I was already quite well acquainted with BLAžEK's research which goes back several decennia with regard to Altaic, Uralic and IndoEuropean linguistics, and consider him an original thinker. SCHWARZ and SRBA, on the other hand, were less known names to me personally, nevertheless with impressive résumés and backgrounds perfectly suitable for this type of cooperative endeavour; SCHWARZ is an expert of sociolinguistics and the languages of the Far East, while Srba is a specialist on both the literary and spoken languages of the Far East and well-versed in the Chinese, Mongolic and Manchu languages and literature. Thus, in combination, the Manual well handles the linguistics, research history, sociolinguistic questions, phonology and lexicon (although excluding comparative lexical data and phonetic correspondences, as this has already been summarized in many other sources) of the Macro-Altaic languages. 


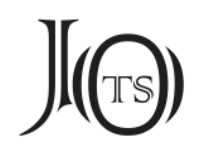

The authors are all veterans in Altaic studies, and have already cooperated with each other in a number of earlier projects, and with this work they have also consulted numerous experts in the field(s) regarding the exchange of sources and ideas (Acknowledgements, p. 13-14) in the production of this English-language corrected volume. We even get an insight into modern Altaic study history using personal anecdotes, almost year by year, described as biographies. ${ }^{1}$ It also seems clear that the authors have usefully delineated Nostratic theory and Altaic theory and have therefore chosen to not overextend the inclusion of reference works on the former.

The book's first chapter (History of recognition of the Altaic languages; p. 15-54) presents the history of descriptive and comparative research of each language, divided into survey bibliography, description, comparative studies, script, etymological dictionaries, comparative grammars, and synthesis - very useful! The description of each Altaic language is interesting and pleasurable to read through, and one gets a sense of the linguistic history having been made throughout the years, and, through the references, what has formed the current state-of-the-art (clearly a goal of this book), insights, beliefs and schools of thought regarding these languages. The subdivision of the linguistic history of each language group into countries, where the research was carried out, is a nice touch since that provides additional insights into the background of current linguistic thinking in these nations.

The second chapter (Distribution and demography of the living languages; p. 5579), deals with information about the ethnic groups of speakers, and numbers of $\left(1^{\text {st }}\right.$ and $2^{\text {nd }}$ language) speakers and the geographic locations of the Altaic languages. Language dialects are also given, as are alternate language names.

\footnotetext{
As an anecdote, this review is the result of BLAŽEK himself -knowing of my own scholarly interestsunexpectedly providing me with a printed copy of this fine volume. I wish to dedicate this review to the memory of Björn COLLINDER, a fellow Swede and one of the leading Uralists of the $20^{\text {th }}$ century, a personal friend and colleague of BLAŽEK, and a known Pro-Altaicist (considering such works as "Uralaltaisch"; 1952). I hope that I have been able to give this monograph a fair and worthy treatment, lifting up strengths and weaknesses alike, about a field that is supremely interesting and in which we still have so much to learn.
} 


\section{J(৫)}

As regards language relationships, chapter three (Models of classification of the Altaic languages; p. 80-123) deals with several different linguistic trees as presented throughout the ages, with only minor commenting, leaving most of the reasoning to the reader. We find earlier trees, for example, where Dagur was mistaken as a Tungusic language (SCHRENCK's model of 1883: 292, on p. 106; PATKANOV's model of 1903-1905, cited by Doerfer 1975: 51-52, on p. 109). Another interesting example is where the Dudke tribe of the Yukaghir, who no doubt were bilingual in Yakut, were regarded West Tungusic, in the Tungusic model by CINciUs, BenZing, Poppe and Menges (p. 111); this is, however, a case of language shift, as are other parts of the same tree, and not the description of a separate Tungusic language per se. The classifications usefully end with very recent tree models (such as those acquired from Ethnologue) thus providing us with the current state-of-the art view.

Chapter four on Etymological analyses of the main ethnonyms or choronyms ( $\mathrm{p}$. 124-155) was unexpected, but nevertheless a welcome addition, as it provides additional background data. The data is very recent, as the Para-Mongolic inscription from Khüis Tolgoi of the beginning of the $7^{\text {th }}$ century, for example, the currently very first attested Altaic language on the steppe, is included (p. 129132).

Then, the compiled phonological charts on the historical phonology of each Altaic language in chapter five (A sketch of the comparative phonetics of the Altaic family; p. 156-181) are extremely useful and up to date, and will no doubt be of great use for modern researchers, including myself, as a chapter to return to repeatedly for consulting. Whether or not one subscribes to the EDAL's (Starostin et al. 2003) overall take on the Altaic languages, some very useful and quite possibly correct ideas regarding Altaic language phonology have been taken therefrom. While the EDAL is heavily criticized in some linguistic circles, perhaps much due to comparisons with overly permissive semantics and lack of argumentation regarding some key questions, it is refreshing to see a publication taking benefit from the EDAL's more insightful, innovative and useful sections.

In chapter six, Nominal case system in the Altaic languages (p. 182-188), we get a taste of Altaic grammar with particular focus on the Turkic languages. The 


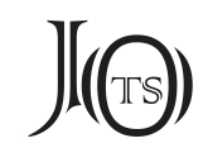

overall thesis is relatively convincing, and as a bonus we get a suggested Altaic proto-language system of nominal cases compiled from the research of known pro-Altaicists.

One assumes that the analysis of numerals, chapter seven (Altaic Numerals in etymological perspective; p. 215-285) comes very naturally to BLAžEK, given his own background in mathematics and physics before a vocation in linguistics, a situation with which I can well sympathize. His early works in this fields include important linguistic papers on numerals in a large number of languages (such as, for example, 1999 \& 2015), and this study interest seemingly culminates as a major part of this volume at hand. Not only are Altaic numerals mentioned, but also numerals from other Paleo-Siberian languages and Cushitic (!), and etymological analyses and considerations are presented. Altaic numerals are characterized by innovation, although a few (' 4 ', ' 5 ', ' 10 ') do appear to originate in a common etymon, while others may be borrowings through substrata or adstrata. As such, the data on the development of numerals, the numerous suggested semantic connections and the phonological correspondences presents a picture of some fairly deep historical language contacts, human migrations and typological and cognitive processes.

The references section, called Bibliography (p. 287-358), is very extensive, and it is clear that no major literature gaps are to be found in this very well researched work (practically encompassing decades of research). The most important (non-author) key references are all there (such as, at a glance, BASHAKOV, Benzing, Bouda, Castrén, Chaoke, Cincius, Clauson, Doerfer, Dolgopolsky, Dybo, EDAL, Georg, Golden, Gombocz, Helimski, Illič-Svityč, Itabashi, Janhunen, KAlyżyński, Kane, Klaproth, Ligeti, Manaster Ramer, Martin, Menges, Miller, Mu-

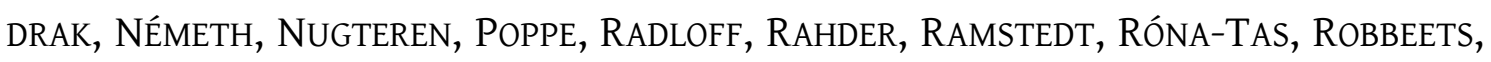
Rozycki, Rybatzki, RäsÄnen, SANŽEev, SCHMidt, Stachowski, STARostin, ŠČERbaK, TODAEVA, UNGER, VASILEVIČ, Vovin, and numerous others). I have been unable to find any "filler" references, so it should all be very useful not only for total beginners just starting out work in the Altaic field, but also for the laymen and veterans of the field alike. 


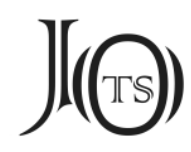

However, some very minor criticism may be in order (with some suggestions for later editions): I would have liked the important and insightful fairly recent paper, actually a lengthy, informed conference speech, detailing Altaic language history and research by S. GEORG (2011), whose other important papers are referenced, to also have been mentioned among the references. While every one of us may in this manner consider some key references to be missing, such matters are subjective indeed. In a completionism perspective, which, however, is no stated objective of this Manual which like any printed material has limited space, a few additional notes could have been made regarding some of the very minor and less documented languages, languages that certainly might interest the specialist. For example, the so-called Sayan Turkic Tuha language, also called Uyghur-Uriankhai, is a language close to Tofan but separate from it. It is included in the classification trees of the Turkic languages (Menges 1968: 86 [here 1968c: 86]²; Johanson 1998: 87; Hammarström-Haspelmath 2017: 88), but no further information can be gleaned about it. To the best of my knowledge, the best current description of it is Ragagnin (2009), but this is not referenced in the volume at all, despite arguably being a key reference. ${ }^{3}$ Further, Tungusic Bala and Alechuxa are listed as dialects of Manchu (p. 74), although some researchers such as Hölzl (2018a; 2018b), actually referenced on p. 113 (where Alechuxa is Alčuka), consider these languages separate from Manchu in a Jurchenic Tungusic subgroup; this Manual is descriptive, not prescriptive, only rarely taking a stance for or against any hypothesis, instead leaving that to the analytic reader. A few references discussing the question of language or dialect could have been useful in such cases. This would have been a trivial addition as numerous tables with lexical comparisons, interrelatedness and genetic language distance are already

\footnotetext{
At a first glance it is not clear what this refers to because there are, in fact, three different MENGES references from that year used in this volume, namely: Menges 1968a, 1968b, 1968c. However, only the last one deals in Turkic studies and it must be the one with the tree diagram. I note that in this Manual there are very few such disambiguous references given, which may happen when new references are added as the manuscript grows, but by checking or pondering each of the options available the right one should be clear enough to the reader.

3 According to personal correspondence, RAGAGNIN does plan to present Tuha word lists in the future, which naturally will be of great interest for the study of Sayan Turkic languages. Other currently similar works are those by Tom Eriksson of the University of Helsinki.
} 


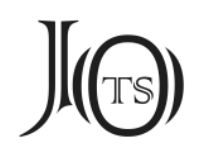

presented. It is, however, to be implicitly understood that interested parties should consult the reference given for of each presented classification tree for further details. In all fairness, my own personal need to find obscure references for obscure languages may not have been the overall goal of this volume, which, granted, does provide excellent starting points for detailed study of numerous Altaic languages.

This volume is perhaps most useful as a guide (or Manual) to Altaic phonology and grammar, and their research history. It should also serve well as a course book on Altaic language theory. An index of topics might have been useful, but the chapters are, in fact, so well named in the Analytical Contents (p. 5-8) that it should be a trivial matter for the reader to find the particular topic he/she is looking for. Due to its solidly descriptive nature, while naturally not completely devoid of such matters, this volume unfortunately leaves out a lot of the wanted theoretical debate, deeper philological and typological analyses and general conclusions regarding the current state of affairs on Altaic studies. For example, it would have been of interest to include a Summary chapter where each of the authors voice their own personal views on the Altaic languages, but, again, this was not the stated intent of this volume, and such matters are left to be published elsewhere.

The printed book follows an easy to use structure, and the electronic version (which is fully searchable) is also adequate for all intended purposes. The printed book is a sturdy hardcover light-blue production on quality paper that will survive well for decades on the bookshelf. Indeed, it will serve well as a bibliographic source on Altaic studies going well beyond a mere primer. The writing style is factual and it is easy to find various threads of interest, with references, where one wishes to continue studies. My estimate is that a dedicated, focused reading of this book, while also taking personal notes and checking up the (many) references - by no means a small task, but perhaps a worthy one! - could produce a well-informed and well-rounded Altaicist. Also, this should be a useful reference bibliography for all current researchers of Altaic languages, and as such this is a timely and useful publication in our days. 


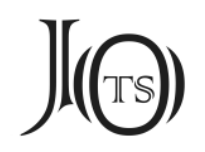

\section{References}

BELYKH, S. (2007). Words of the Middle Mongolian Origin in the Permic Languages, Idnakar, 2/2: 33-39.

BlAžEK, V. \& M. SCHWARZ (2015). "Numerals in Mongolic and Tungusic languages with notes to code-switching", Proceedings of the $12^{\text {th }}$ Seoul International Altaistic Conference, Multidimensional understandings of languages and cultures of Altaic people, The Altaic Society of Korea/Institute of Altaic Studies, Seoul National University, Seoul: $11-20$.

BLAŽEK, V. (1999). Comparative-Etymological analyses of numeral systems and their implications. Brno: Spisy Masarykovy university.

COLLINDER, B. (1952) “Uralaltaisch”, Uralaltaische Jahrbücher, 24/3-4: 1-26.

DoERfer, G. (1975). “Ist Kur-Urmiisch ein nanaischer Dialekt?”, Ural-Altaische Jahrbücher, 47: 51-63.

GEORG, S. (2011). "The Poverty of Altaicism. An oral presentation held at the symposium “Altaique ou pas?", Organized by Guillaume Jacques and Anton Antonov on $10^{\text {th }}$ December 2011 in Paris. (Found online at: https://www.academia.edu/1638942/The_Poverty_of_Altaicism [Retrieved: 2019-10-01]).

HAMmarström, H. F. F. \& M. Haspelmath (2017) "Turkic", Glottolog 3.0. Jena, Germany: Max Planck Institute for the Science of Human History (Found online at: https://glottolog.org/resource/languoid/id/bolg1249 [retrieved 2019-10-08]).

HöLzL, A. (2018a). "Udi, Udihe, and the language(s) of the Kyakala”, International Journal of Diachronic Linguistics and Linguistic Reconstruction, 15: 111-146.

HöLzL, A. (2018b). “The Tungusic language family through the ages: Interdisciplinary perspectives: Introduction", Presented at International Workshop at the $51^{\text {st }} \mathrm{An}$ nual Meeting of the Societas Linguistica Europaea (29 August - 1st September 2018, Tallinn University, Estonia).

JoHANSON, L. (1998). “The History of Turkic”, The Turkic Languages, Ed. by L. JoHANSON \& Éva Á. CSATó, Routledge, London \& New York: 81-83.

KARI, J. \& B. A. POTTER (2010). “The Dene-Yeniseian Connection”, Anthropological Papers of the University of Alaska, 5/1-2. 


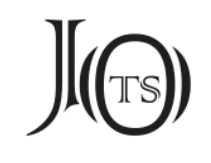

MENGES, K. H. (1968a). "Die tungusische Sprachen”, Tungusologie, Ed. by W. Fuchs, Brill, Leyden: 21-256.

MeNGES, K. H. (1968b). Tungusen und Ljao, Wiesbaden: Steiner Verlag.

MENGES, K. H. (1968c). The Turkic languages and peoples. An introduction to Turkic studies, Wiesbaden: Harrassowitz Verlag.

Nugteren, H. (2011). Mongolic Phonology and the Qinghai-Gansu Languages, Utrecht: LOT.

PIISPANEN, P. S. (2013).” The Uralic-Yukaghiric connection revisited: Sound correspondences of Geminate clusters", Journal de la Société Finno-Ougrienne, 94: 165-197.

PiISPANEN, P. S. (2019). “Additional Turkic and Tungusic Borrowings into Yukaghir II”, Journal of Old Turkic Studies, 3/1: 54-82.

RAGAGNin, E. (2009). "A rediscovered lowland Tofan variety in northern Mongolia", Turkic Languages, 13: 225-245.

RÉDEI, K. (1988-1991). Uralisches Etymologisches Wörterbuch, Budapest: Akadémiai Kiadó.

ScHÖNIG, C. (2003). "Turko-Mongolic Relations", the Mongolic Languages, Ed. J. JANHUNEN, Routledge, London and New York: 403-420.

SCHRENCK von, L. (1883) Ob inorodcax Amurskogo kraja I, St. Petersburg: Imperatorskaja Akademija Nauk.

Starostin, Sergei et al. (2003). An Etymological Dictionary of Altaic Languages, Leiden: Brill. 